\title{
A Complete Monographic Study on Abies pindrow Royle Aerial Parts
}

\author{
D. KUMAR AND S. KUMAR
}

Centre for Advanced Research in Indian System of Medicine (CARISM), SASTRA University, Thanjavur-613 401, India

Kumar, et al.: A Complete Monograph on Abies pindrow

The establishment of pharmacognostic standards of traditional plants is prerequisite for selecting authenticated plants for research purpose. The pharmacognostic standards of an Indian traditional plant, i.e., Abies pindrow Royle (silver fir; family- Pinaceae) has been established. Transverse section of leaf through midrib showed presence of epidermis, palisade cells, vascular bundles, spongy cells, phloem and xylem whereas stem showed the presence of cork, cortex, pericyclic fibres, phloem, xylem and pith. Pitted vessel, pericyclic fibre, unicellular covering trichome and anomocytic stomata were observed in powdered microscopy. Total ash was about 2 and 4 times more than acid insoluble and water soluble ash, respectively. Alcohol soluble extractive value was found to be slightly less than water soluble extractive value. Foreign organic matter, moisture and tannin contents were found to be nil, $8.03 \%$ and $2.11 \% \mathrm{w} / \mathrm{w}$, respectively. Swelling index, foaming index, bitterness value and haemolytic value were found to be $1.2,<100,4000$ and nil, respectively. Volatile oil content was found to be $0.85 \% \mathrm{v} / \mathrm{w}$. Quantitative chemical parameters viz., acid-, saponification-, ester-, hydroxyl-, iodine-, peroxide-, acetyl values and unsaponifiable matter for the volatile oil were also generated. The content of toxic residues was estimated and found to comply with the limits as per World Health Organization. Phytochemically, the plant was found to contain fats, triterpenoids, flavonoids, steroids, tannins, proteins and carbohydrates. Thin layer chromatography of n-hexane, chloroform, methanol extracts and volatile oil showed eleven, eight, ten and eleven spots, respectively, using suitable mobile phases.

Key words: Abies pindrow, ash value, extractive value, moisture content, silver fir

Abies pindrow Royle commonly known as Himalayan silver fir, belongs to family Pinaceae. It is widely distributed at elevations between 2000-3000 m throughout the Western Himalayas from Afghanistan to Nepa ${ }^{[1]}$. Traditionally, the plant has been used in the treatment of anxiety, pain and inflammation ${ }^{[2]}$. The plant has been reported to exhibit antiinflammatory ${ }^{[3]}$, anxiolytic ${ }^{[4]}$ antioxidant ${ }^{[5]}$ and bronchospasm activities $^{[6]}$. Chalcone glycosides, flavonoids, fatty acids, hydrocarbons and terpenoids have been isolated from $A$. pindrow ${ }^{[7-10]}$.

Recently, researchers are exploring natural resources to develop newer and safer drugs for the effective treatment of various diseases. Investigating plants, based on their traditional uses becomes a sound, viable and costeffective strategy ${ }^{[11]}$. In case of herbals, standardization has prime importance because it ensures the quality of plant material, which will contribute to its safety and efficacy $^{[12]}$. A thorough survey of literature revealed that despite a long tradition of use for the treatment

*Address for correspondence E-mail: thakur_pu@yahoo.com

November-December 2017 of various ailments, no systematic phytochemical and pharmacological work has ever been carried out on this traditionally used and clinically potential plant with a view to isolate bioactive constituent(s) responsible for biological activities.

Non-availability of pharmacognostic standards to authenticate this plant may be one of the reasons that sporadic phytochemical and pharmacological reports are available on $A$. pindrow. Thus, the present investigations were planned with an objective to establish pharmacognostic standards for $A$. pindrow thereby facilitating authentication of the correct plant material.

This is an open access article distributed under the terms of the Creative Commons Attribution-NonCommercial-ShareAlike 3.0 License, which allows others to remix, tweak, and build upon the work non-commercially, as long as the author is credited and the new creations are licensed under the identical terms

Accepted 16 October 2017

Revised 04 April 2017

Received 20 June 2016

Indian J Pharm Sci 2017;79(6):1001-1007 


\section{MATERIALS AND METHODS}

All the chemicals, reagents and solvents including bacoside A, quinine hydrochloride, chloral hydrate (Reidel Research Laboratory, Hapur, India), anisaldehyde (Central Drug House Pvt. Ltd., Mumbai, India), hide powder (Panacea Biotech, Lalru, India), laboratory grade reagents such as glycerine, ethanol, methanol, chloroform, petroleum ether, n-hexane, acetonitrile, toluene, bromine, hydrochloric acid, nitric acid, formic acid, phenolphthalein, potassium hydrogen phthalate, potassium hydroxide, potassium iodate, sodium chloride, potassium iodide, sodium thiosulphate, sulphuric acid, acetic anhydride, carbon tetrachloride, diethyl ether, glacial acetic acid, sodium hydroxide, potassium chlorate, ferric chloride, sodium citrate, iodine, ammonia, ninhydrin, magnesium turnings, picric acid, mercuric iodide, potassium bismuth iodide, disodium hydrogen phosphate, potassium dihydrogen phosphate, lead acetate, sodium nitroprusside, sodium picrate, Fehling's A, Fehling's B, Benedict's reagent, $\alpha$-naphthol and pyridine (E-Merck Ltd., Mumbai; S. D. Fine-Chem Ltd., Biosar, India), were used in the present investigations.

\section{Plant material:}

Abies pindrow aerial parts were collected from Gulaba Kothi, Manali, Himachal Pradesh, India in September, 2012. Identity of the plant was confirmed in the Raw Materials Herbarium and Museum, National Institute of Science Communication and Information Resources (NISCAIR), New Delhi (Reference No. NISCAIR/ RHMD/Consult/2013/2242/23, dated 21/05/2013).

\section{Macroscopic and microscopic studies:}

The macroscopic studies of $A$. pindrow aerial parts were separately studied by observing the external characters. Qualitative and quantitative microscopic studies on the plant were carried out using compound microscope. Observations were made using $10 \mathrm{X}$ eye piece and $10 \mathrm{X}$ or $40 \mathrm{X}$ objectives.

Micrometric determinations viz., length and width of bordered pitted vessels, pericyclic fibres and trichomes were made using eye and stage micrometer. Photomicrographs were taken using binocular photomicrographic apparatus attached with digital camera. Dried aerial parts of $A$. pindrow were boiled with water until soft. Thin sections of plant parts were cut by sharp blades, transferred on slides, cleared by warming with chloral hydrate aqueous solution
$(250 \% \mathrm{w} / \mathrm{v})$ and mounted in glycerine aqueous solution $(50 \% \mathrm{v} / \mathrm{v})$.

Similarly, powdered plant materials (\# 60) were also cleared with chloral hydrate and mounted in glycerine. For micrometric determinations, plant materials were disintegrated using Schult'z maceration fluid. Schult'z maceration fluid was prepared by adding sufficient potassium perchlorate to aqueous nitric acid $(50 \% \mathrm{v} / \mathrm{v})$ to maintain a steady but gentle effervescence while heating on a water bath.

A fragment of the plant material was placed in above macerating fluid. Potassium perchlorate was added time to time till tissues softened and disintegrated. The treated tissue was taken on a slide, teased with a mounted needle and repeatedly washed with water to free the acid. Length and width of the bordered pitted vessels, pericyclic fibres and trichomes (50 observations for each) were recorded using a calibrated eye piece micrometer ${ }^{[13]}$.

Petroleum ether-, alcohol- and water-soluble extractive values, total ash, acid insoluble ash and water soluble ash of dried powdered aerial parts of the plant were determined following the procedures given in the Indian Pharmacopoeia ${ }^{[14]}$. Ash was prepared in a Muffle Furnace (Narang Scientific Works, New Delhi, India). All weightings were made using digital weighing balance (Ohaus, USA).

Foreign organic matter in $A$. pindrow aerial parts was determined by spreading $100 \mathrm{~g}$ aerial parts on clear smooth surface background by using a 10X magnifying lens ${ }^{[15]}$. The experiment was performed in triplicate.

The moisture content was determined by azeotropic distillation method following the procedure given in Indian Pharmacopoeia ${ }^{[14]}$. The experiment was done in triplicate. Toluene was used in the determination of moisture content.

Coarsely powdered aerial parts ( $5 \mathrm{~g}$ each) were taken in round bottom flasks and $200 \mathrm{ml}$ of prepared toluene was added. The flask was heated gently on heating mantle till its contents began to boil. Then, distillation was carried out at the rate of about 2 drops per second until most of the water had distilled over. Finally, the rate was increased to about 4 drops per second which was maintained for $5 \mathrm{~min}$.

Bitterness and haemolytic values of dried powdered aerial parts was determined following the procedures given in the World Health Organization (WHO) ${ }^{[15]}$. Bitterness value is determined by comparison with 
quinine hydrochloride, the bitterness value of which is set at 200000 . Swelling and foaming index of dried powdered aerial parts were determined following the procedures given in the $\mathrm{WHO}^{[15]}$.

Determination of tannin in dried powdered aerial parts of the plant was made following the procedures given in the $\mathrm{WHO}^{[15]}$.

Volatile oil content was determined following the procedure given in United States Pharmacopoeia/ National Formulary using Clevenger Apparatus (PerfitGupta Scientific Industry, Ambala ${ }^{[16]}$. The experiment was performed in triplicate. Refractive index and specific gravity of volatile oil were also determined.

Various quantitative chemical tests viz., acid value, saponification value, ester value, hydroxyl value, peroxide value, iodine value, acetyl value and unsaponifiable matter of the volatile oil were done following the procedure given in Indian Pharmacopoeia ${ }^{[14]}$.

The fluorescence character of the aerial parts was studied both in daylight and UV light (254 and $366 \mathrm{~nm}$ ) and after treatment with different reagents like formic acid, glacial acetic acid, sulphuric acid, hydrochloric acid, nitric acid, ammonia solution, iodine, ferric chloride and potassium hydroxide ${ }^{[17]}$.

Quantitative determinations of aflatoxins, heavy metals, arsenic, pesticides and microbial content in A. pindrow aerial parts were done at analytical laboratory of OSCAR Analytical Pvt. Ltd. Baddi, Solan (Certificate No. OAPL/1962/09FXIII, dated 09/06/2013). These determinations were made as per the procedures described in $\mathrm{WHO}^{[15]}$.

\section{Phytochemical screening of various extracts:}

Aerial parts were dried under sunlight and powdered in a grinder. Dried powdered plant material (250 g) was extracted in a Soxhlet apparatus (Perfit, Ambala, India) successively using solvents in increasing order of polarity viz., n-hexane, chloroform and methanol.

The water extract was prepared by boiling the marc of plant material with distilled water for $2 \mathrm{~h}$ on a hot plate. The solvents and water from crude extracts were recovered under reduced pressure using rotary vacuum evaporator (Buchi, Switzerland) to get n-hexane extract, chloroform extract, methanol extract and water extract. Various extracts were subjected to phytochemical screening to ascertain various classes of phytoconstituents present therein ${ }^{[18]}$.

\section{Thin layer chromatography (TLC) of extracts and volatile oil:}

Precoated aluminium based TLC plates (Merck, Silica gel G, $0.2 \mathrm{~mm}$ ) were used to generate fingerprint profiles of various extracts and volatile oil. Dried powder aerial parts $(25 \mathrm{~g})$ were extracted in a similar manner as described in section 'phytochemical screening of various extracts'.

The dried n-hexane, chloroform and methanol extracts were dissolved in $3 \mathrm{ml}$ of respective solvents, and their volume was made up to $5 \mathrm{ml}$ in volumetric flasks. Ten microliters of the standard solution of each extract was loaded on TLC plates using Camag Linomat 5.

The thin layer chromatograms were visualized by spraying with $0.5 \%$ anisaldehyde followed by heating at $105^{\circ}$ for $2 \mathrm{~min}^{[19]}$. Similarly, TLC fingerprint profile of volatile oil extracted from fresh aerial parts was performed.

\section{RESULTS AND DISCUSSION}

A. pindrow is a tall evergreen tree having conical crown with level branches. The leaves are needle-like in shape, dark green in colour, 3-8 cm in length, 0.2$0.4 \mathrm{~cm}$ width, perfumery odour and bitter taste. Stems are greyish-pink to buff-brown, smooth and glabrous (hairless).

The transverse section of leaf through midrib region of $A$. pindrow showed the presence of epidermis, palisade cells, vascular bundles, spongy cells, phloem and xylem whereas transverse section of stem showed the presence of cork, cortex, pericyclic fibres, phloem, xylem and pith (fig. 1 and 2).

Representative photomicrographs of pitted vessel, pericyclic fibre, trichomes and stomata (fig. 3). Mean values of length and width of pitted vessels, pericyclic fibres and trichomes of $A$. pindrow aerial parts are depicted in Table 1.

Results of various physiochemical parameters of A. pindrow aerial parts are presented in Table 2. Results of mean values of various quantitative chemical parameters viz., acid value, saponification value, ester value, hydroxyl value, iodine value, peroxide value, unsaponifiable matter and acetyl value for the volatile oil of $A$. pindrow aerial parts are presented in Table 3 . Table 4 shows fluorescence analysis of dried powder of $A$. pindrow aerial parts with various reagents. Tables 5 and 6 shows aflatoxins, heavy metals, mercury, 


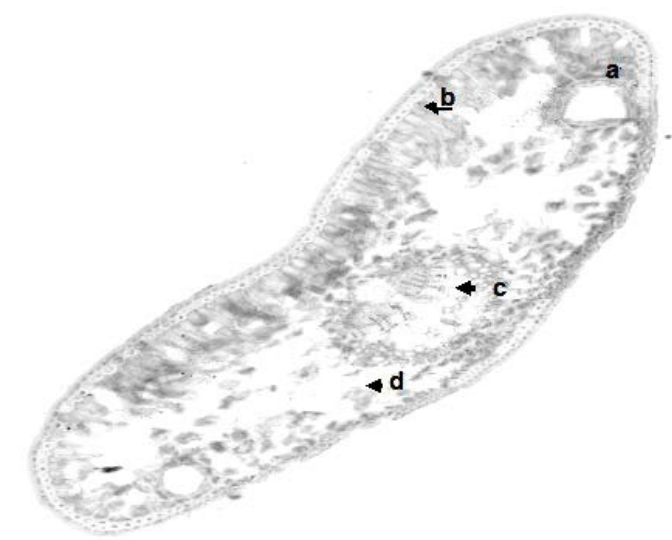

(A)

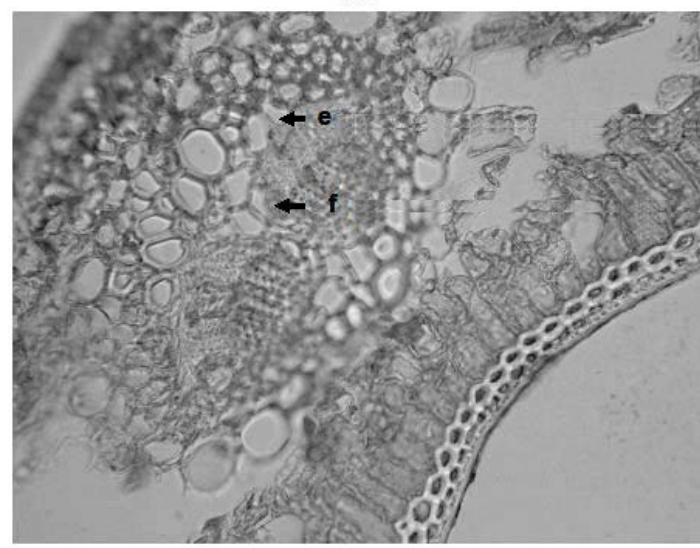

(B)

Fig. 1: Representative photomicrographs of transverse section of $A$. pindrow leaf

A: 100X; B: 400X. (a), Epidermis; (b), palisade cells; (c), vascular bundles; (d), spongy cells; (e), phloem; (f), xylem

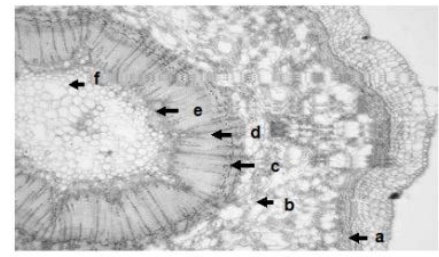

(A)
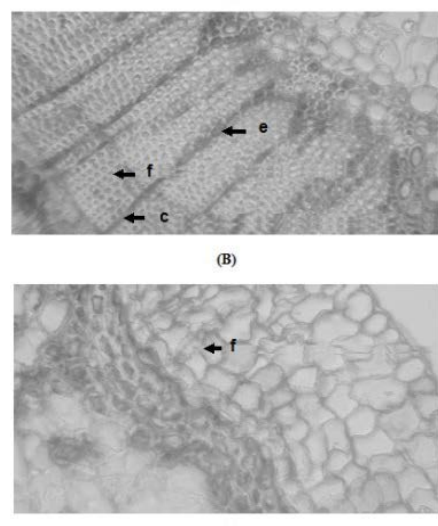

Fig. 2: Representative photomicrographs of transverse section of $A$. pindrow stem

A: 100X; B: 400X; C: 400X. (a), Cork; (b), cortex; (c), pericyclic fibres; (d), phloem; (e), xylem; (f), pith

1004

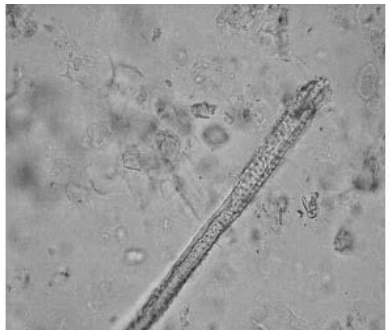

(A)

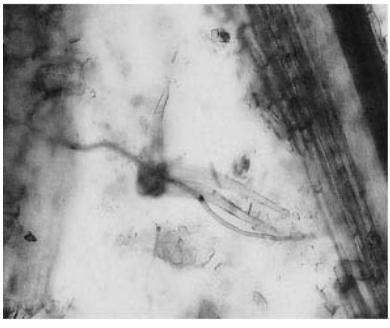

(C)

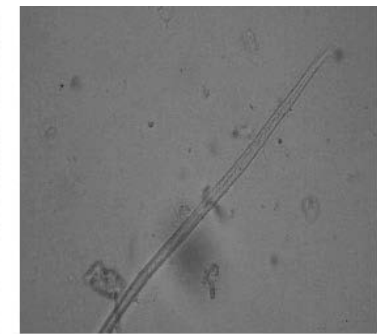

(B)

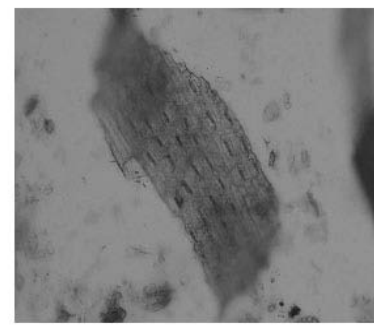

(D)

Fig. 3: Representative photomicrographs (400X)

(A) Vessel; (B) pericyclic fibre; (C) trichomes and (D) lower epidermis showing stomata in powdered aerial parts of $A$. pindrow

TABLE 1: MEAN VALUES OF LENGTH AND WIDTH OF TRICHOMES, BORDERED PITTED VESSELS AND PERICYCLIC FIBRES OF A. PINDROWAERIAL PARTS

\begin{tabular}{ll}
\hline Parameter & Mean $^{\mathrm{n}}$ length/width $(\mu \mathrm{m}$, range $)$ \\
\hline Trichomes & $201.11 / 8.39$ \\
& $(190.31-209.79 / 6.71-9.03)$ \\
\multirow{2}{*}{ Bordered pitted vessels } & $275.31 / 11.87$ \\
& $(269.33-283.79 / 9.91-12.35)$ \\
Pericyclic fibres & $679.87 / 14.57$ \\
& $(640.37-699.81 / 12.11-16.89)$ \\
\hline
\end{tabular}
$\mathrm{n}=50$

TABLE 2: MEAN VALUES OF VARIOUS PHYSICOCHEMICAL PARAMETERS OF A. PINDROW AERIAL PARTS

\begin{tabular}{|c|c|}
\hline Parameters & Observations \\
\hline Total ash* & $9.53 \pm 0.03 \% \mathrm{w} / \mathrm{w}$ \\
\hline Acid insoluble ash* & $4.20 \pm 0.03 \% \mathrm{w} / \mathrm{w}$ \\
\hline Water soluble ash* & $2.23 \pm 0.03 \% \mathrm{w} / \mathrm{w}$ \\
\hline Sulphated ash* & $10.20 \pm 0.06 \% \mathrm{w} / \mathrm{w}$ \\
\hline $\begin{array}{l}\text { Petroleum ether soluble extractive } \\
\text { value* }^{*}\end{array}$ & $1.71 \pm 0.01 \% \mathrm{w} / \mathrm{w}$ \\
\hline Alcohol soluble extractive* & $13.36 \pm 0.04 \% \mathrm{w} / \mathrm{w}$ \\
\hline Water soluble extractive* & $17.83 \pm 0.05 \% \mathrm{w} / \mathrm{w}$ \\
\hline Moisture content** & $8.03 \pm 0.07 \% \mathrm{w} / \mathrm{w}$ \\
\hline Foreign organic matter** & Nil \\
\hline Swelling index* & $1.2 \pm 0.20$ \\
\hline Foaming index* & Less than $100 \pm 0.00$ \\
\hline Bitterness value* & $4,000 \pm 0.00$ \\
\hline Haemolytic value* & Nil \\
\hline Tannin determination* & $2.11 \pm 0.01 \% \mathrm{w} / \mathrm{w}$ \\
\hline $\begin{array}{l}\text { Volatile oil*** } \\
\text { Refractive index/specific gravity }\end{array}$ & $\begin{array}{c}0.85 \pm 0.00 \% \mathrm{v} / \mathrm{w} \\
1.47 \pm 0.02 / 0.86 \pm 0.00\end{array}$ \\
\hline & $1.71 \pm 0.0210 .0010 .00$ \\
\hline
\end{tabular}


TABLE 3: MEAN VALUES OF VARIOUS QUANTITATIVE CHEMICAL PARAMETERS OF VOLATILE OIL OBTAINED FROM A. PINDROW AERIAL PARTS

\begin{tabular}{lc}
\hline Parameter & Mean $^{\mathrm{n}}$ Value \\
\hline Acid value & $8.42 \pm 0.03$ \\
Saponification value & $50.49 \pm 0.05$ \\
Ester value & $42.07 \pm 0.07$ \\
Hydroxyl value & $821.87 \pm 0.15$ \\
lodine value & $29.16 \pm 0.01$ \\
Peroxide value & $8.05 \pm 0.05$ \\
Unsaponifiable matter & $80.02 \pm 0.07$ \\
Acetyl value & $63.92 \pm 0.01$ \\
\hline $\mathrm{n}=3$ &
\end{tabular}

TABLE 4: FLUORESCENCE ANALYSIS OF A. PINDROW AERIAL PARTS

\begin{tabular}{|c|c|c|c|}
\hline \multirow[b]{2}{*}{ Treatment } & \multirow[b]{2}{*}{$\begin{array}{l}\text { Visible } \\
\text { light }\end{array}$} & \multicolumn{2}{|c|}{ Ultraviolet light } \\
\hline & & $\begin{array}{c}\text { Short } \\
\text { wavelength } \\
(254 \mathrm{~nm})\end{array}$ & $\begin{array}{c}\text { Long } \\
\text { wavelength } \\
(366 \mathrm{~nm})\end{array}$ \\
\hline Toluene & Green & Green & Blackish \\
\hline Chloroform & Green & Green & Reddish \\
\hline Hexane & Green & Green & Green \\
\hline Ethyl acetate & Green & Green & Green \\
\hline Methanol & Green & Green & Green \\
\hline Formic acid & Green & Green & Blackish \\
\hline Glacial acetic acid & Green & Green & Dark reddish \\
\hline $\begin{array}{l}\text { Dilute sulphuric } \\
\text { acid }\end{array}$ & Green & Green & Dark green \\
\hline $\begin{array}{l}\text { Dilute hydrochloric } \\
\text { acid }\end{array}$ & $\begin{array}{l}\text { Light } \\
\text { green }\end{array}$ & Green & Dark blackish \\
\hline Dilute nitric acid & $\begin{array}{l}\text { Reddish } \\
\text { brown }\end{array}$ & Brown & Black \\
\hline Dilute ammonia & Green & Green & Dark brown \\
\hline $5 \%$ lodine & Green & Green & Dark green \\
\hline $5 \%$ Ferric chloride & Green & Green & Black \\
\hline $\begin{array}{l}1 \text { M Potassium } \\
\text { hydroxide }\end{array}$ & $\begin{array}{l}\text { Dark } \\
\text { green }\end{array}$ & Green & Brown \\
\hline
\end{tabular}

arsenic, pesticides residue, and microbial content in A. pindrow aerial parts. A. pindrow aerial parts were successively extracted using solvents in increasing order of polarity viz., n-hexane, chloroform, methanol and water. Percent yields $(\mathrm{w} / \mathrm{w})$ of extracts of A. pindrow aerial parts are shown in Table 7. All extracts of $A$. pindrow aerial parts were dissolved in their respective solvents and screened for different classes of phytoconstituents using specific standard reagents. All extracts were screened for presence of different classes of phytoconstituents. The results of phytochemical screening have been shown in Table 8. Results of TLC of various extracts and volatile oil of $A$. pindrow aerial parts are shown in Table 9 and fig. 4. Finally, it can be concluded that a complete
TABLE 5: AFLATOXINS, HEAVY METALS, MERCURY, ARSENIC AND PESTICIDES RESIDUE IN A. PINDROW AERIAL PARTS

\begin{tabular}{|c|c|c|}
\hline Parameters & Observations & $\begin{array}{c}\text { Limit } \\
\text { (as prescribed } \\
\text { by WHO) }\end{array}$ \\
\hline $\begin{array}{l}\text { Aflatoxins } B_{1} \\
B_{2} \\
G_{1} \\
G_{2} \\
\text { Total }\end{array}$ & $\begin{array}{l}\text { Absent } \\
\text { Absent } \\
\text { Absent } \\
\text { Absent } \\
\text { Absent }\end{array}$ & Should be absent \\
\hline $\begin{array}{l}\text { Heavy metals: lead, } \\
\text { cadmium, mercury, } \\
\text { arsenic }\end{array}$ & Absent & $\begin{array}{l}\text { NMT } 1 \text { ppm } \\
\text { NMT } 5 \text { ppm } \\
\text { NMT } 3 \text { ppm }\end{array}$ \\
\hline $\begin{array}{l}\text { Pesticides: aldrin, } \\
\text { azinphos-methyl, } \\
\text { cypermethrin, } \\
\text { chlordane, } \\
\text { chlorfenviphos, } \\
\text { chlorpyrofos, } \\
\text { carbophenothion, } \\
\text { dimethoate, diazinon, } \\
\text { Dichlorvos, dieldrin, } \\
\text { DDT, eldrin, ethion, } \\
\text { endosulfan, fenitrothion, } \\
\text { fensalfothion, fonofos, } \\
\text { heptachlor, cis and trans } \\
\text { heptachlorepoxide, } \\
\text { hexachlorocyclohexane, } \\
\text { hexachlorobenzene, } \\
\text { heptachlor, } \\
\text { lindane, malathion, } \\
\text { methidathion, } \\
\text { parathion, permethrin, } \\
\text { phosalone, pyrethrins, } \\
\text { pirimiphos-methyl }\end{array}$ & Absent & Should be absent \\
\hline
\end{tabular}

TABLE 6: MICROBIAL AND PATHOGEN CONTENT IN A. PINDROW AERIAL PARTS

\begin{tabular}{|c|c|c|}
\hline Microbes & Observations & $\begin{array}{c}\text { Limit } \\
\text { (as prescribed } \\
\text { by WHO) }\end{array}$ \\
\hline Total microbial count & $26 \mathrm{cfu} / \mathrm{gm}$ & NMT 1000 cfu/g \\
\hline $\begin{array}{l}\text { Total yeast and mould } \\
\text { count }\end{array}$ & Absent & NMT $100 \mathrm{cfu} / \mathrm{g}$ \\
\hline $\begin{array}{l}\text { Salmonella } \\
\text { typhymurium }\end{array}$ & Absent & Should be absent \\
\hline Escherichia coli & Absent & Should be absent \\
\hline $\begin{array}{l}\text { Pseudomonas } \\
\text { auroginosa }\end{array}$ & Absent & Should be absent \\
\hline Staphylococcus aureus & Absent & Should be absent \\
\hline Clostridium botulinum & Absent & Should be absent \\
\hline Clostridium perfringens & Absent & Should be absent \\
\hline Clostridium tetani & Absent & Should be absent \\
\hline
\end{tabular}

monographic study helps the natural product scientists in authenticating $A$. pindrow for phytochemical and pharmacological work. 
TABLE 7: PERCENTAGE YIELDS OF VARIOUS EXTRACTS OF A. PINDROW AERIAL PARTS

\begin{tabular}{lc}
\hline Extract & Percentage yield $(\% \mathrm{w} / \mathrm{w})$ \\
\hline $\mathrm{HE}$ & 3.20 \\
$\mathrm{CE}$ & 4.10 \\
$\mathrm{ME}$ & 10.60 \\
$\mathrm{WE}$ & 16.10 \\
\hline
\end{tabular}

TABLE 8: PHYTOCHEMICAL SCREENING OF VARIOUS EXTRACTS OF $A$. PINDROW AERIAL PARTS

\begin{tabular}{lcccc}
\hline Class of phytoconstituents & HE & CE & ME & WE \\
\hline Alkaloids & - & - & - & - \\
Anthraquinone glycosides & - & - & - & - \\
Cyanogenetic glycosides & - & - & - & - \\
Cardiac glycosides & - & - & - & - \\
Steroids/triterpenoids & - & $-/+$ & $+/+$ & - \\
Saponins & - & - & - & + \\
Flavonoids & - & - & + & - \\
Coumarins & - & - & - & - \\
Tannins & - & - & - & + \\
Carbohydrates & - & - & + & + \\
Proteins & - & - & + & + \\
Fixed oils/fats & + & - & - & - \\
\hline
\end{tabular}

+ Present, - absent

TABLE 9: THIN LAYER CHROMATOGRAPHY OF VARIOUS EXTRACTS AND VOLATILE OIL OF A. PINDROW AERIAL PARTS

\begin{tabular}{|c|c|c|}
\hline Extract & Mobile phase & Number of spots* \\
\hline $\mathrm{HE}$ & $\begin{array}{c}\text { Hexane:chloroform } \\
(2: 3)\end{array}$ & $\begin{array}{c}\text { Eleven spots; } R_{f} \text { values: } \\
0.07,0.11,0.15,0.27 \\
0.38,0.42,0.54,0.60 \\
0.82,0.89 \text { and } 0.93\end{array}$ \\
\hline CE & $\begin{array}{l}\text { Chloroform:methanol: } \\
\text { acetonitrile: glacial } \\
\text { acetic acid (18:1:1:1) }\end{array}$ & $\begin{array}{c}\text { Eight spots; } R_{f} \text { values: } \\
0.06,0.13,0.28,0.46 \\
0.51,0.63,0.72 \text { and } 0.81\end{array}$ \\
\hline ME & $\begin{array}{l}\text { Toluene:ethyl acetate: } \\
\text { methanol }(2: 1: 1)\end{array}$ & $\begin{array}{c}\text { Ten spots; } R_{f} \text { values: } \\
0.12,0.16,0.21,0.28 \\
0.35,0.40,0.55,0.63 \\
0.70 \text { and } 0.83\end{array}$ \\
\hline $\begin{array}{l}\text { Volatile } \\
\text { oil }\end{array}$ & $\begin{array}{l}\text { Toluene:ethyl } \\
\text { acetate }(4: 1)\end{array}$ & $\begin{array}{c}\text { Eleven spots; } R_{f} \text { values: } \\
0.06,0.17,0.19,0.23 \\
0.38,0.57,0.66,0.75 \\
0.81,0.87 \text { and } 0.93\end{array}$ \\
\hline
\end{tabular}

*Spots were visualized by spraying with $0.5 \%$ anisaldehyde followed by heating for $2 \mathrm{~min}$ at $105^{\circ}$

\section{Acknowledgements:}

The financial assistance provided by University Grants Commission, New Delhi (F. No. 41-735/2012 (SR), dated 23/07/2012) for the present research work is duly acknowledged. The authors thank Dr. Sunita Garg, Chief Scientist and Head, Raw Materials Herbarium and Museum, National Institute of Science Communication

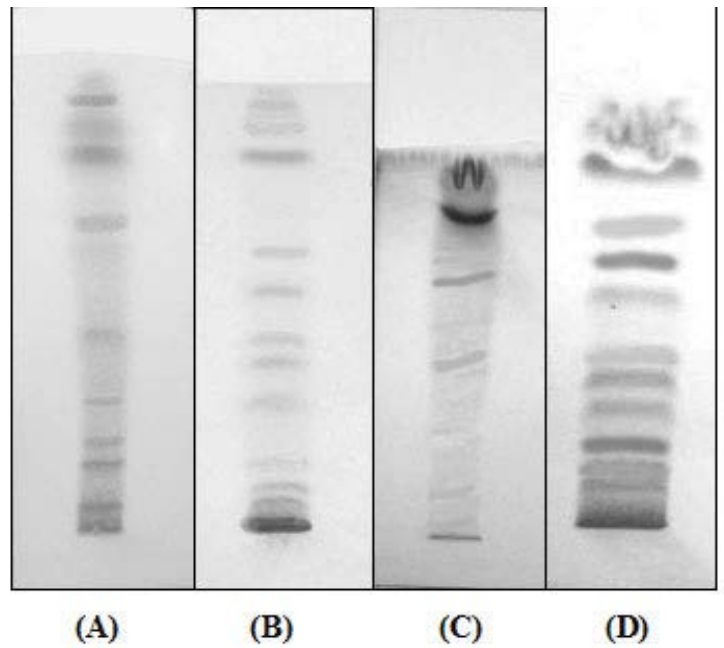

Fig. 4: Representative photographs of thin layer chromatograms (A) Volatile oil; (B) HE; (C) CE and (D) ME of $A$. pindrow aerial parts

and Information Resources (NISCAIR), New Delhi for confirming the identity of the plant.

\section{Conflict of interest:}

The authors declare that they have no conflict of interest.

\section{Financial support and sponsorship:}

Nil.

\section{REFERENCES}

1. Kirtikar KR, Basu BD. Indian Medicinal Plants. Allahabad: International Book Distributors; 1975. p. 13.

2. Quattrocchi U. CRC World Dictionary of Medicinal and Poisonous Plants: Common Names, Scientific Names, Eponyms, Synonyms and Etymology. Boca Raton: CRC Press; 2012. p. 5.

3. Singh RK, Pandey BL. Further study of anti-inflammatory effects of Abies pindrow. Phytother Res 1997;2:535-7.

4. Kumar D, Kumar S. Screening of antianxiety activity of Abies pindrow Royle aerial parts. Indian J Pharm Educ Res 2015;49:66-70.

5. Kumar D, Jamwal A, Madaan R, Kumar S. Evaluation of antioxidant activity of selected Indian medicinal plants. J Fund Pharm Res 2014;2:1-10.

6. Singh RK, Bhattacharya SK, Acharya SB. Pharmacological activity of Abies pindrow. J Ethnopharmacol 2000;73:47-51.

7. Tiwari KP, Minocha PK. A chalcone glycoside from $A$. pindrow. Phytochemistry 1980;19: 2501-3.

8. Tripathi M, Jain L, Pandey VB, Ray AB, Rucker G. Pindrolactone, a lanostane derivative from the leaves of $A b i e s$ pindrow. Phytochemistry 1996;43:853-5.

9. Burdi, DK, Samejo MQ, Bhanger MI, Khan KM. Fatty acid composition of Abies pindrow (West Himalayan Fir). Pak J Pharm Sci 2007;20:9-15.

10. Samejo MQ, Burdi DK, Bhanger MI, Talpur FN, Khan KM. 
Identification of hydrocarbons from Abies pindrow leaves. Chem Nat Compd 2010;46:132-4.

11. Kumar D, Kumar S. Evaluation of antianxiety activity of Calotropis gigantea roots. J Fund Pharm Res 2014;2:30-7.

12. Chanda S. Importance of pharmacognostic study of medicinal plants: An overview. J Phcog Phytochem 2014;2:69-73.

13. Kokate CK, Purohit AP, Gokhale SB. Text Book of Pharmacognosy. Pune: Nirali Prakashan; 1999. p. 74.

14. Indian Pharmacopeia. New Delhi: Ministry of Health and Family Welfare, Government of India, Controller of Publications; 1996. p. A48, A50-A54, A96, A99.

15. World Health Organization (WHO). Quality Control Methods for Medicinal Plant Materials. England: Office of Publications; 1998. p. 8-64.
16. United States Pharmacopeia/National Formulary. Rockville, Maryland: The National Formulary, United States Pharmacopoeial Convention Inc., 12601 Twinbrook Parkway, MD; 1990. p. 1550.

17. Kumar D, Kumar K, Kumar S, Kumar T, Kumar A, Prakash O. Pharmacognostic evaluations of leaf and root bark of Holoptelea integrifolia Roxb. Asian Pac J Trop Biomed 2012:2:169-75.

18. Farnsworth NR. Biological and phytochemical screening of plants. Int J Pharm Sciences 1966;55:225-76.

19. Madaan R, Singh B, Kumar S. Pharmacognostic standardization of Conium maculatum. J Pharm Biomed Sci 2010;1:1-5. 